\title{
RESPON KANDUNGAN LOGAM BERAT DAN PERTUMBUHAN TANAMAN SAWI (Brassica juncea) TERHADAP KOMBINASI MEDIA TANAM LUMPUR LAPINDO DAN MIKORIZA
}

\author{
${ }^{1)}$ Army Dita Serdani, ${ }^{2)}$ Jeka Widiatmanta \\ Fakultas Pertanian, Universitas Islam Balitar \\ E-mail: ${ }^{1}$ ditaarmy@gmail.com
}

\begin{abstract}
ABSTRAK
This research is the development of the use of Lapindo mud and mycorrhizae as a planting medium. Lapindo mud contains nutrients such as $\mathrm{N}, \mathrm{P}, \mathrm{K}, \mathrm{Na}, \mathrm{Ca}, \mathrm{Mg}$, $\mathrm{C}$ organic and has a high cation exchange capacity. Mycorrhizae can increase the length of plant roots and are resistant to stress and soils contaminated with heavy metals. The study was arranged using a Randomized Block Design with factorial patterns, the first factor being the planting medium (A) and the second factor was mycorrhizae (P). The first factor is Lapindo mud and cow manure; Lapindo mud and goat manure; Lapindo mud and chicken manure with a ratio of 50\%: 50\%, respectively. From these two factors, 9 treatment combinations were obtained, namely A1P1, A1P2, A1P3, A2P1, A2P2, A2P3, A3P1, A3P2, and A3P3. Each treatment was repeated 3 times to obtain 27 experimental units. From the study found that there is a real interaction in providing a combination of planting media and mycorrhizae on the growth and yield of mustard plants. The best treatment combination was shown in the combination treatment of planting media (Lapindo mud and cow manure) with 10 gr mycorrhizae / plants (A1P2) on all observations (plant height, number of leaves, leaf area, fresh and dry weight of plants, root length, weight, weight wet and dry weight of root of mustard plants and absorption of heavy metal content).
\end{abstract}

Keyword: Lapindo Mud, Mustard Plant, Mycorrhizae, Planting Media

\section{PENDAHULUAN}

Lumpur Lapindo merupakan sebutan bagi lumpur panas yang keluar akibat proses pengeboran yang dilakukan oleh Lapindo Brantas Inc di Kecamatan Porong, hingga saat ini masih menjadi problematika [1]. Lumpur lapindo yang terus menyembur mengakibatkan volume lumpur semakin bertambah dan mengendap menjadi hamparan tanah yang luas. Endapan tersebut memiliki tekstur liat, debu dan pasir [2], hara yang tinggi seperti $\mathrm{N}, \mathrm{P}, \mathrm{K}, \mathrm{Na}, \mathrm{Ca}, \mathrm{Mg}, \mathrm{C}$ organik dan kapasitas pertukaran kation yang tinggi. Kemampuan tersebut menjadi dasar untuk mengeksploitasi lumpur lapindo sebagai tempat tumbuh tanman dengan ditambahkan mikoriza dan bahan organik.

Penggunaan bahan organik dapat berasal dari pupuk kandang (pukan) dari sapi, ayam maupun kambing yang akan memperbaiki tanah yaitu memperbaiki struktur tanah, $\mathrm{pH}$ tanah, meningkatkan mikrofauna dan mikroflora tanah dan mengurangi sumber pencemaran lingkungan. Pupuk kandang memiliki manfaat yaitu memperbaiki struktur dan tekstur tanah, mempercepat infiltrasi, sebgai sumber makanan bagi tanaman dan organisme dalam tanah [3]. Pada tanaman cabai keriting penggunaan pupuk kandang sebanyak 20 ton per hektarnya dapat meningkatkan pertumbuhan dan hasil[4]. 
Selain penambahan bahan organik, peningkatan kondisi fisik, kimia dan biologi tanah dapat dilakukan dengan pemberian mikoriza. Mikoriza merupakan jamur yang bersimbiosis dengan akar tanaman. Peran mikoriza yaitu membantu penyerapan unsur hara utamanya unsur $\mathrm{P}$, dapat bertahan pada daerah cekaman utamanya cekaman air dan kontaminasi logam berat, meningkatkan hasil dan pertumbuhan tanaman [5]. Mikoriza yang telah bersimbiosis dengan tanaman akan membentuk miselium yang membantu dalam meningkatkan areal serapan akar sehingga tanaman dapat memperoleh nutrisi dengan baik.

Penelitian ini bertujuan untuk memanfaatkan lumpur lapindo sebagai media tanam yang ditambahkan bahan organik dan mikoriza. Tanaman sawi (Brassica juncea L.) dipilih karena bersifat toleran terhadap logam berat. Harapannya ialah tanaman sawi akan menyerap logam berat yang akan mempengaruhi pertumbuhan dan hasil serta dapat diketahui besaran serapan logam berat pada tanaman sawi.

\section{METODE PENELITIAN}

Penelitian dilaksanakan di rumah plastik di Kelurahan Kanigoro Kecamatan Kanigoro bulan Juni sampai dengan Desember 2019. Peralatan yang digunakan adalah cangkul, ember, cetok, timbangan, gunting, gembor, alat tulis, polibag, timbangan digital, Alat AAS, oven, penggaris, papan namadan kamera. Bahan yang digunakan adalah lumpur lapindo, pupuk kandang (sapi, kambing dan ayam), mikoriza, dan sawi hijau Var. Prima.

Penelitian dirancang dengan menggunakan Rancangan Acak Kelompok (RAK) yang disusun secara faktorial dan diulang sebanyak tiga kali. Faktor pertama media tanam (A) dan faktor kedua mikoriza (P) masing-masing terdiri dari tiga level.

Faktor I : media tanam

A1 : pukan sapi : mikoriza $(1: 1)$

A2 : pukan kambing : mikoriza (1:1)

A3 : pukan ayam : mikoriza $(1: 1)$

Faktor II : mikoriza

$\mathrm{P} 1$ : dosis mikoriza 5 gram/ tanaman

$\mathrm{P} 2$ : dosis mikoriza $10 \mathrm{gram} /$ tanaman

$\mathrm{P} 3$ : dosis mikoriza $15 \mathrm{gram} /$ tanaman

Variabel pengamatan tinggi tanaman, jumlah daun, luas daun, bobot segar dan bobot kering tajuk tanaman, panjang akar, bobot segar akar, bobot kering akar, dan kandungan logam berat dengan metode AAS (Atomic Absorption Spectrometry)

\section{Pelaksanaan Penelitian dan Analisis Data}

Media tanam terdiri dari tanah top soil, pupuk kandang, endapan lumpur lapindo dan mikoriza dan dimasukkan kedalam polibag berukuran $25 \times 25 \mathrm{~cm}$ sesuai perlakuan. Kemudian menanaminya dengan bibit sawi yang telah berumur 14 hari setelah benih ditanam, atau daun berjumlah tiga sampai empat helai. Pemeliharaan tanaman dilakukan dengan penyiraman, penyiangan dan pengendalian organisme pengganggu tanaman (OPT) dengan menggunakan pestisida. Data yang diperoleh dianalisis dengan metode analisis ragam berdasarkan uji $\mathrm{F}$ dengan taraf $5 \%$. 


\section{HASIL DAN PEMBAHASAN}

\section{Tinggi Tanaman}

Dari tabel 1 menunjukkan bahwa media tanam dapat meningkatkan tinggi tanaman sawi hijau. Perlakuan pukan kambing dan lumpur lapindo (A2) berbeda nyata terhadap perlakuan pukan sapi dan lumpur lapindo (A1) dan perlakuan pukan ayam dan lumpur lapindo (A3).

Tabel 1. Rerata tinggi tanaman sawi (B. juncea) pada Beberapa Kombinasi Media Tanam dan Dosis Mikoriza pengamatan 7,14,21,28 dan 35 hst

\begin{tabular}{lrrrrl}
\hline \multicolumn{1}{c}{ Perlakuan } & \multicolumn{5}{c}{ Tinggi Tanaman (cm) } \\
\cline { 2 - 6 } & $7 \mathrm{hst}$ & $14 \mathrm{hst}$ & $21 \mathrm{hst}$ & $28 \mathrm{hst}$ & $35 \mathrm{hst}$ \\
\hline \multicolumn{1}{c}{ Media Tanam } & & & & & \\
A1 (Lumpur Lapindo dan pukan & $12.50 \mathrm{~b}$ & $16.17 \mathrm{~b}$ & $19.87 \mathrm{~b}$ & $23.90 \mathrm{~b}$ & $29.70 \mathrm{~b}$ \\
$\begin{array}{l}\text { Sapi) } \\
\text { A2 ( Lumpur Lapindo dan pukan }\end{array}$ & & & & & \\
$\begin{array}{l}\text { Kambing) } \\
\text { A3 ( Lumpur Lapindo dan pukan }\end{array}$ & $8.77 \mathrm{a}$ & $10.81 \mathrm{a}$ & $13.06 \mathrm{a}$ & $18.12 \mathrm{a}$ & $20.96 \mathrm{a}$ \\
Ayam) & $11.86 \mathrm{~b}$ & $15.63 \mathrm{~b}$ & $18.76 \mathrm{~b}$ & $23.07 \mathrm{~b}$ & $28.78 \mathrm{~b}$ \\
$\quad$ & & & & & \\
P1 ( Dosis Mr/tanaman) & $11.28 \mathrm{a}$ & $14.25 \mathrm{a}$ & $17.46 \mathrm{a}$ & $21.49 \mathrm{a}$ & $26.51 \mathrm{ab}$ \\
P2 ( 10 gr/tanaman) & $11.30 \mathrm{a}$ & $14.55 \mathrm{a}$ & $17.74 \mathrm{a}$ & $23.73 \mathrm{~b}$ & $27.85 \mathrm{~b}$ \\
P3 ( 15 gr/tanaman) & $10.55 \mathrm{a}$ & $13.82 \mathrm{a}$ & $16.49 \mathrm{a}$ & $20.76 \mathrm{a}$ & $25.07 \mathrm{a}$ \\
\hline
\end{tabular}

Keterangan : Angka pada baris dan kolom yang sama diikuti huruf yang sama berarti tidak berbeda nyata pada uji Duncan $(\alpha=0,05)$.

Media tanam dapat meningkatkan rerata tinggi tanaman sawi hijau (tabel 1) dari umur 7 hst sampai 35 hst, dimana penggunaan media tanam campuran lumpur lapindo dan pukan sapi (A1) dan perlakuan lumpur lapindo media dan pukan ayam (A3) menunjukkan hasil rerata tinggi tanaman yang lebih baik dari perlakuan lumpur lapindo dan pukan kambing (A2). Hal ini menunjukkan bahwa penggunaan media tanam mampu meningkatkan tinggi tanaman sawi hijau. Hal ini diduga ketersediaan unsur hara pada media tanam telah tersedia sehingga dapat diserap oleh tanaman dan meningkatkan tinggi tanaman. Peningkatan tinggi tanaman dapat dipengaruhi oleh kadar Nitrogen yang cukup bagi tanaman dimana pupuk kandang sapi mengandung $\mathrm{N}$ tinggi yang bermanfaat bagi tanaman [6].

Penambahan mikoriza pada media tidak berpengaruh nyata pada tinggi tanaman sawi pada umur 7 hst hingga 21 hst, namun berbeda nyata pada tanaman berumur 28 hst. Penambahan mikoriza dengan dosis $10 \mathrm{gr} / \mathrm{tanaman}$ (P2) menunjukkan hasil yang lebih baik dibandingkan perlakuan P1 dan P3. Pada awal pertumbuhan tanaman perlakuan mikoriza berpengaruh tidak nyata. Hal ini diduga mikoriza membutuhkan waktu untuk melakukan penetrasi hingga berkolonisasi. Pemberian mikoriza dapat diberikan pada saat persemaian sehingga mikoriza dapat berkolonisasi pada tanaman dan mampu mengikat unsur P [7]. 


\section{Jumlah Daun}

Pada tabel 2 menunjukkan bahwa reratajjumlah daun tanaman sawi dipengaruhi oleh mdia tanam dalam hal ini ialah lumpur lapindodan pupuk kandang. Perlakuan dengan media tanam lumpur lapindo dan pukan sapi (A1) dan lumpur lapindo dan pukan ayam (A3) memiliki rerata jumlah daun yang lebih baik dari perlakuan media tanam lumpur lapindo dan pukan kambing (A2). Pada umur tanaman 35 hst menunjukkan bahwa campuran media tanam dan pukan sapi memiliki rerata jumlah daun terbaik daripada perlakuan A1 dan A2. Hal ini diduga dengan penambahan pupuk kandang dapat menyediakan unsur hara $\mathrm{N}$ dan $\mathrm{P}$ pada tanaman, sehingga sel akan aktif membelahutamanya ialah daerah meristem. Menurut [8] adanya sel yang aktif membelah, pemanjangan daerah meristem akan meningkatkan pertambahan tinggi tanaman, jumlah daun, diameter tajuk.

Tabel 2. Rerata Jumlah Daun Tanaman Sawi Hijau (B. juncea) pada Beberapa Kombinasi Media Tanam Dan Dosis Mikoriza Pengamatan 7,14,21,28 dan 35 hst

\begin{tabular}{|c|c|c|c|c|c|}
\hline \multirow{2}{*}{ Perlakuan } & \multicolumn{5}{|c|}{ Jumlah Daun (Helai) } \\
\hline & $7 \mathrm{hst}$ & $14 \mathrm{hst}$ & $21 \mathrm{hst}$ & $28 \mathrm{hst}$ & $35 \mathrm{hs}$ \\
\hline Lumpur Lapindo & & & & & \\
\hline $\begin{array}{l}\text { A1 (Lumpur Lapindo dan pukan Sapi) } \\
\text { A2 ( Lumpur Lapindo dan pukan }\end{array}$ & $4.22 \mathrm{~b}$ & $4.37 \mathrm{~b}$ & $5.68 \mathrm{~b}$ & $7.07 \mathrm{~b}$ & $9.03 \mathrm{c}$ \\
\hline Kambing) & $3.54 \mathrm{a}$ & $3.77 \mathrm{a}$ & $4.07 \mathrm{a}$ & $4.48 \mathrm{a}$ & $5.05 \mathrm{a}$ \\
\hline $\begin{array}{c}\text { A3 ( Lumpur Lapindo dan pukan Ayam) } \\
\text { Dosis Mikoriza }\end{array}$ & $3.97 \mathrm{~b}$ & $4.35 \mathrm{~b}$ & $5.47 \mathrm{~b}$ & $6.58 \mathrm{~b}$ & $8.25 \mathrm{~b}$ \\
\hline P1 ( 5 gr/tanaman) & $3.86 \mathrm{a}$ & $4.08 \mathrm{a}$ & $5.10 \mathrm{ab}$ & $6.00 \mathrm{a}$ & $7.27 \mathrm{a}$ \\
\hline $\mathrm{P} 2$ ( $10 \mathrm{gr} / \mathrm{tanaman})$ & $3.97 \mathrm{a}$ & $4.32 \mathrm{a}$ & $5.32 \mathrm{~b}$ & $6.54 \mathrm{~b}$ & $8.44 \mathrm{~b}$ \\
\hline P3 ( 15 gr/tanaman) & $3.90 \mathrm{a}$ & $4.09 \mathrm{a}$ & $4.80 \mathrm{a}$ & $5.59 \mathrm{a}$ & $6.89 \mathrm{a}$ \\
\hline
\end{tabular}

Keterangan : Angka pada baris dan kolom yang sama diikuti huruf yang sama berarti tidak berbeda nyata pada uji Duncan $(\alpha=0,05)$.

Penambahan dosis mikoriza pada awal pertumbuhan tanamanmenunjukkan tidak berpengaruh nyata dan berpengaruh nyata pada tanaman umur 35 hst. Pada umur tanaman 35 hst menunjukkan pemberian dosis mikoriza sebanyak $10 \mathrm{gr} / \mathrm{tanaman}$ (P2) berbeda nyata dengan pemberian dosis 5 gr/tanaman (P1) dan dosis $15 \mathrm{gr} / \operatorname{tanaman}(\mathrm{P} 3)$. Pemberian dosis mikoriza sebanyak $10 \mathrm{gr} / \operatorname{tanaman}$ (P2) menunjukkan pertumbuhan jumlah daun tanaman sawi hijau yang lebih baik karena mampu meningkatkan jumlah daun tanaman hingga panen dibandingkan dengan perlakuan P1 dan P3.

\section{Luas Daun}

Pengamatan luas daun dilakukan pada tanaman sawi umur 7, 14, 21, 28, dan 35 hst. Berdasarkan hasil analisis sidik ragam menunjukkan bahwa terdapat interaksi yang nyata pada perlakuan pemberian media tanam lumpur lapindo dan dosis mikoriza terhadap rata-rata luas daun tanaman sawi. Pemberian media tanam dan mikoriza mampu meningkatkan rata-rata luas daun tanaman sawi (tabel 3). 
Copyright@UNISBA Blitar, http://ejournal.unisbablitar.ac.id/index.php/viabel

Army Dita Serdani \& Jeka Widiatmanta 2019. Respon Kandungan Logam Berat dan Pertumbuhan Tanaman Sawi (Brassica juncea) Terhadap Kombinasi Media Tanam Lumpur Lapindo dan Mikoriza Journal Viabel Pertanian. (2019), 13(2)16-25

Tabel 3. Rerata Luas Daun Tanaman Sawi Hijau (B. juncea) pada Beberapa Kombinasi Media Tanam dan Dosis Mikoriza

\begin{tabular}{llllll}
\hline \multirow{2}{*}{ Perlakuan } & \multicolumn{5}{c}{ Luas Daun $\left(\mathrm{cm}^{2}\right)$} \\
\cline { 2 - 6 } & $7 \mathrm{hst}$ & $14 \mathrm{hst}$ & $21 \mathrm{hst}$ & $28 \mathrm{hst}$ & $35 \mathrm{hst}$ \\
\hline A1P1 & $26.69 \mathrm{~b}$ & $35.21 \mathrm{bc}$ & $40.95 \mathrm{~b}$ & $68.94 \mathrm{~b}$ & $89.32 \mathrm{~b}$ \\
A1P2 & $37.75 \mathrm{bc}$ & $44.99 \mathrm{c}$ & $55.38 \mathrm{~d}$ & $65.22 \mathrm{~b}$ & $124.25 \mathrm{c}$ \\
A1P3 & $33.28 \mathrm{~b}$ & $42.89 \mathrm{c}$ & $47.18 \mathrm{c}$ & $78.80 \mathrm{~b}$ & $112.32 \mathrm{c}$ \\
A2P1 & $18.95 \mathrm{a}$ & $22.28 \mathrm{a}$ & $25.48 \mathrm{a}$ & $35.23 \mathrm{a}$ & $68.00 \mathrm{a}$ \\
A2P2 & $16.87 \mathrm{a}$ & $21.56 \mathrm{a}$ & $24.81 \mathrm{a}$ & $42.41 \mathrm{a}$ & $70.82 \mathrm{a}$ \\
A2P3 & $14.39 \mathrm{a}$ & $17.44 \mathrm{a}$ & $24.79 \mathrm{a}$ & $40.68 \mathrm{a}$ & $59.78 \mathrm{a}$ \\
A3P1 & $33.38 \mathrm{~b}$ & $46.22 \mathrm{c}$ & $49.90 \mathrm{~cd}$ & $50.74 \mathrm{ab}$ & $116.99 \mathrm{c}$ \\
A3P2 & $26.14 \mathrm{~b}$ & $33.08 \mathrm{~b}$ & $35.98 \mathrm{~b}$ & $40.81 \mathrm{a}$ & $115.71 \mathrm{c}$ \\
A3P3 & $26.00 \mathrm{~b}$ & $31.27 \mathrm{~b}$ & $43.70 \mathrm{bc}$ & $63.63 \mathrm{~b}$ & $99.80 \mathrm{bc}$ \\
\hline
\end{tabular}

Keterangan : Angka pada baris dan kolom yang sama diikuti huruf yang sama berarti tidak berbeda nyata pada uji Duncan $(\alpha=0,05)$.

Perlakuan A1P2 (kombinasi media tanam lumpur lapindo pukan sapi dan mikoriza $110 \mathrm{gr} /$ tanaman) cenderung menunjukkan hasil rerata luas daun yang paling tinggi dibandingkan kombinasi-kombinasi yang lain baik pada pengamatan 7 hingga 35 hst. Perlakuan A2P1, A2P2 dan A2P3 cenderung mimiliki luas daun rendah, perlakuan tersebut merupakan kombinasi lumpur lapindo dan pukan kambing dengan berbagai dosis mikoriza 5, 10 dan $15 \mathrm{gr} / \mathrm{tanaman}$.

Pertumbuhan tanaman ditandai dengan adanya pembelahan dan pemanjangan sel hal ini erat kaitannya dengan ketersediaan unsur hara bagi tanaman. Pada tanaman golongan Brassicaceae unsur hara nitrogen sangat memiliki peran dalam pertumbuhan dan perkembangan daun. [9] menyatakan penambahan luas daun dipengaruhi oleh meristem yang aktif membelah seperti meristem apikal yang terletak pada ujung akar dan batang tanaman, sel sel kan aktif membelah dan memanjang, sehingga akan menambah luasan daun. Menurut [10], keadaan tanaman dengan ciri diameter tajuk lebih luas menandakan tersedianya nitrogen pada media tumbuh. Mikoriza diduga telah berkoloni dan mampu mengoptimalkan serapan unsur $\mathrm{P}$, sehingga unsur hara makro pada tanaman dapat tersedia dan mampu meningkatkan luas daun tanaman.

\section{Bobot Segar dan Bobot Kering Tanaman}

Pada tabel 4 dapat dilihat bahwa terdapat pengaruh interaksi yang nyata pada perlakuan media tanam (A) dan dosis mikoriza (P) terhadap bobot segra dan bobot kering tanaman saat panen. Kombinasi media tanam lumpur lapindo dan mikoriza dapat dilihat pada Tabel 4. Berdasarkan tabel 4 dapat di lihat bahwa rata-rata bobot segar tanaman tertinggi pada perlakuan kombinasi kombinasi media tanam lumpur lapindo dan pukan sapi ditambah mikoriza dengan dosis $10 \mathrm{gr} / \mathrm{tanaman}$ (A1P2) merupakan perlakuan tertinggi pada pengamatan bobot segar tanaman yang diamati saat panen yaitu sebesar 101,22 gram. Begitu juga dengan bobot kering A1P2 sebesar 19,2 gram.

Hal ini diduga komposisi media tanam saling mendukung, dengan penambahan mikoriza dan pupuk kandang mampu menetralkan lumpur lapindo. Pupuk kandang diduga mampu menambah unsur hara pada media sehingga dapat terserap oleh tanaman dan mempengaruhi bobot segar tanaman. Menurut [11], pada daerah yang terdampak logam berat diberi bahan organik dan kapur dapat meningkatkan produksi biomassa tanaman. 
Copyright@UNISBA Blitar, http://ejournal.unisbablitar.ac.id/index.php/viabel

Army Dita Serdani \& Jeka Widiatmanta 2019. Respon Kandungan Logam Berat dan Pertumbuhan Tanaman Sawi (Brassica juncea) Terhadap Kombinasi Media Tanam Lumpur Lapindo dan Mikoriza Journal Viabel Pertanian. (2019), 13(2)16-25

Tabel 4. Rerata Bobot Segar dan Bobot Kering Tanaman Sawi Hijau (B. juncea) pada Beberapa Kombinasi Media Tanam dan Dosis Mikoriza

\begin{tabular}{lcc}
\hline Perlakuan & Bobot Segar $(\mathrm{gr})$ & Bobot Kering $(\mathrm{gr})$ \\
\hline $\mathrm{A} 1 \mathrm{P} 1$ & $69.11 \mathrm{bc}$ & $18.1 \mathrm{c}$ \\
$\mathrm{A} 1 \mathrm{P} 2$ & $101.22 \mathrm{~cd}$ & $19.2 \mathrm{c}$ \\
$\mathrm{A} 1 \mathrm{P} 3$ & $51.89 \mathrm{~b}$ & $17.8 \mathrm{c}$ \\
$\mathrm{A} 2 \mathrm{P} 1$ & $16.33 \mathrm{a}$ & $9,7 \mathrm{a}$ \\
$\mathrm{A} 2 \mathrm{P} 2$ & $28.00 \mathrm{ab}$ & $13,2 \mathrm{~b}$ \\
$\mathrm{~A} 2 \mathrm{P} 3$ & $15.22 \mathrm{a}$ & $7,7 \mathrm{a}$ \\
A3P1 & $77.88 \mathrm{c}$ & $17.4 \mathrm{c}$ \\
A3P2 & $52.00 \mathrm{~b}$ & $17.1 \mathrm{c}$ \\
A3P3 & $36.44 \mathrm{~b}$ & $16.1 \mathrm{bc}$ \\
\hline Ke
\end{tabular}

Keterangan : Angka pada baris dan kolom yang sama diikuti huruf yang sama berarti tidak berbeda nyata pada uji Duncan $(\alpha=0,05)$.

Pertumbuhan tanaman dan banyaknya unsur hara yang terserap tanaman dapat dilihat dari bobot kering tanaman. Semakin besar bobot kering tanaman, menunjukkan pertumbuhan tanaman tersebut baik danunsur hara serta air yang terserap tanaman tercukupi[12]. Mikoriza juga mampu bertahan pada daerah cekaman, miskin hara maupun air. [13] menjelaskan, bahwa pemberian takaran fungi mikoriza $10 \mathrm{~g} /$ tanamam dapat meningkatkan pertumbuhan dan produksi tanaman.

\section{Panjang Akar, Bobot Segar Akar, dan Bobot Kering Tanaman Sawi}

Berdasarkan hasil analisis sidik ragam (Anova) pada taraf 5\% terdapat pengaruh interaksi yang nyata pada pemberian media tanam lumpur lapindo (A) dan dosis mikoriza(P) terhadap panjang akar tanaman sawi hijau saat panen. Berdasarkan tabel 6 dapat di lihat bahwa kombinasi terbaik yaitu kombinasi media tanam lumpur lapindo dan pukan sapi ditambah mikoriza dengan dosis $10 \mathrm{gr} / \mathrm{tanaman}$ (A1P2) pada panjang akar $(26,82 \mathrm{~cm})$, berat segar (7,0 gram) akar dan berat kering akar (3,02 gram) tanaman sawi. 
Copyright@UNISBA Blitar, http://ejournal.unisbablitar.ac.id/index.php/viabel

Army Dita Serdani \& Jeka Widiatmanta 2019. Respon Kandungan Logam Berat dan Pertumbuhan Tanaman Sawi (Brassica juncea) Terhadap Kombinasi Media Tanam Lumpur Lapindo dan Mikoriza Journal Viabel Pertanian. (2019), 13(2)16-25

Tabel 5. Rerata Panjang Akar, Bobot Segar Akar dan Bobot Kering Akar Tanaman Sawi Hijau (B. juncea) pada Beberapa Kombinasi Media Tanam dan Dosis Mikoriza

\begin{tabular}{lccc}
\hline Perlakuan & $\begin{array}{c}\text { Panjang Akar } \\
\text { Tanaman }(\mathrm{cm})\end{array}$ & $\begin{array}{c}\text { Bobot Segar Akar } \\
\text { Tanaman }(\mathrm{gr})\end{array}$ & $\begin{array}{c}\text { Bobot Kering Akar } \\
\text { Tanaman }(\mathrm{gr})\end{array}$ \\
\hline $\mathrm{A} 1 \mathrm{P} 1$ & $14.08 \mathrm{a}$ & $4.00 \mathrm{bc}$ & $1.35 \mathrm{a}$ \\
$\mathrm{A} 1 \mathrm{P} 2$ & $26.82 \mathrm{~b}$ & $7.00 \mathrm{e}$ & $3.02 \mathrm{~d}$ \\
$\mathrm{~A} 1 \mathrm{P} 3$ & $17.05 \mathrm{a}$ & $5.5 \mathrm{de}$ & $2.29 \mathrm{bc}$ \\
$\mathrm{A} 2 \mathrm{P} 1$ & $11.83 \mathrm{a}$ & $2.91 \mathrm{a}$ & $1.34 \mathrm{a}$ \\
$\mathrm{A} 2 \mathrm{P} 2$ & $14.05 \mathrm{a}$ & $3.62 \mathrm{~b}$ & $1.28 \mathrm{a}$ \\
$\mathrm{A} 2 \mathrm{P} 3$ & $11.61 \mathrm{a}$ & $4.1 \mathrm{bc}$ & $2.2 \mathrm{~b}$ \\
$\mathrm{~A} 3 \mathrm{P} 1$ & $15.72 \mathrm{a}$ & $5.33 \mathrm{~d}$ & $1.83 \mathrm{~b}$ \\
$\mathrm{~A} 3 \mathrm{P} 2$ & $15.72 \mathrm{a}$ & $4.68 \mathrm{c}$ & $2.3 \mathrm{c}$ \\
A3P3 & $14.74 \mathrm{a}$ & $3.7 \mathrm{bc}$ & $2.4 \mathrm{c}$ \\
\hline
\end{tabular}

Keterangan : Angka pada baris dan kolom yang sama diikuti huruf yang sama berarti tidak berbeda nyata pada uji Duncan $(\alpha=0,05)$.

Pemberian mikoriza dapat memperpanjang akar, hal ini dipengaruhi oleh mikoriza masuk ke dalam jaringan tanaman kemudian melakukan penetrasi dan membentuk miselium. Miselium ini akan merangsang perpanjangan mantel akar, sehingga akar tanman semakin panjang. Akar tanaman yang sedemikian rupa diharapkan mampu meningkatkan absorbsi serapan unsur hara dan air. Menurut [14]mikoriza akan membentuk arbuskula yaitu hifa bercabang halus yang berfungsi sebagai tempat menyimpan karbon dan tempat penyerapan hara tanaman. Hal ini akan berdampak pada bobot segar akar dan bbot kering akar tanaman sawi. Dari hasil rerata bobot kering akar menunjukkan bahwa semakin besar pemberian mikoriza maka hasil bobot kering akar semakin besar. Pada penelitian tanaman sawi yang diberi mikoriza sebanyak 10 gram dengan kombinasi pukan sapi dapat menghasilkan bobot kering yang tinggi. Hal ini diduga kombinasi tersebut ideal untuk perkembangan mikoriza.

\section{Kandungan Logam Berat yang Terdapat pada Daun Tanaman Sawi setelah Perlakuan}

Tanaman sawi yang sudah diambil dikering anginkan kemudian diujikan bagian daun tanman sawi untuk mengetahui macam kandungan logam berat yang ikut terserap selama pertumbuhan tanaman. Daun tanaman sawi mengandung beberapa macam logam berat yaitu $\mathrm{P}, \mathrm{S}, \mathrm{K}, \mathrm{Ca}, \mathrm{Mn}, \mathrm{Fe}, \mathrm{Ni}, \mathrm{Cu}, \mathrm{Zn}, \mathrm{Br}$, Mo dan $\mathrm{Re}$. Untuk mengetahui kadar jumlah logam berat yang terkandung maka dilakukan pengujian pada beberapa logam berat seperti tembaga $(\mathrm{Cu})$, besi $(\mathrm{Fe})$, Krom $(\mathrm{Cr})$ dan nikel $(\mathrm{Ni})$. Pemilihan keempat logam berat ini berdasarkan kadar jumlah kandungan logam berat pada lumpur lapindo. Kadar logam berat tembaga $(\mathrm{Cu})$, besi $(\mathrm{Fe})$, Krom $(\mathrm{Cr})$ dan nikel $(\mathrm{Ni})$ dapat dilihat pada gambar 1. 


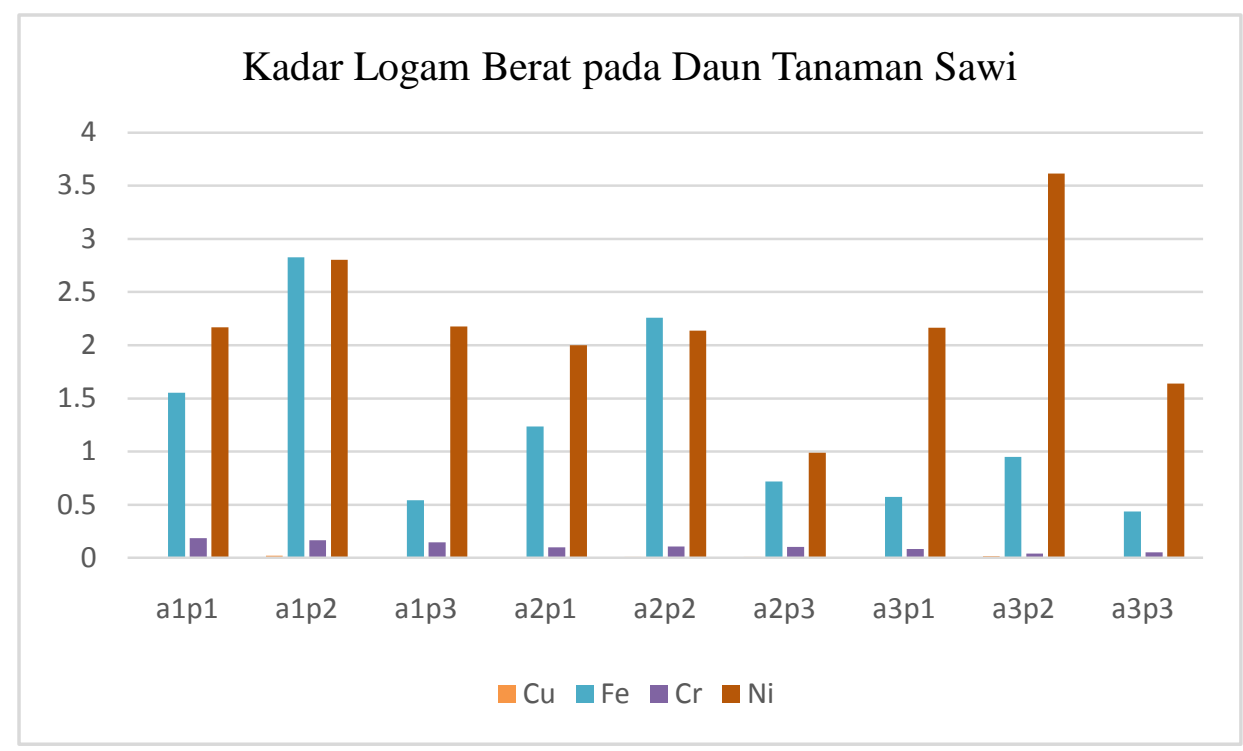

Gambar 1. Perbandingan Kadar Kandungan Logam Berat $\mathrm{Cu}, \mathrm{Fe}, \mathrm{Cr}$, dan $\mathrm{Ni}$ pada Tanaman

Dari gambar 1 dapat terlihat bahwa terjadi serapan logam berat pada tanaan sawi akibat perlakuan media tanam dan mikoriza.

Secara keseluruhan terjadi serapan logam pada tanaman akibat penambahan lumpur lapindo. Perlakuan A1P2 mampu menyerap logam berat dengan jumlah tinggi dibandingkan perlakuan lainnya. Sementara itu serapan logam berat nikel tertinggi pada perlakuan A3P2. Sementara untuk perlakuan A1P2 serapan Fe dan Ni relatif sama besar. Meskipun logam berat bersifat racun bagi tanaman tetapi pada jumlah yang seimbang dapat memiliki peran bagi pertumbuhan tanaman. $\mathrm{Cu}$ dan $\mathrm{Fe}$ berperan dalam pembentukan protein klorofil [15], dengan pembentukan klorofil yang sempurna . proses respirasi dapat berjalan sehingga akar tanaman dapat menyerap hara dengan baik.

\section{KESIMPULAN}

Hasil penelitian respon kandungan logam berat dan pertumbuhan tanaman sawi terhadap media tanam dan mikoriza yang telah dilakukan dapat disimpulkan sebagai berikut:

1. Terdapat interaksi yang nyata pada perlakuan media tanam dan mikoriza terhadap pertumbuhan dan hasil tanaman sawi. Hal inidibuktikan pada setiap parameter pengamatan menunjukkan nilai adanya pengaruh signifikan atau sangat nyata.

2. Kombinasi perlakuan terbaik ditunjukkan pada perlakuan kombinasi media tanam lumpur lapindo pukan sapi dan pemberian mikoriza 10 gr/tanaman (A1P2) pada semua pengamatan. 


\section{UCAPAN TERIMAKASIH}

Ucapan terimakasih kepada pihak-pihak yang mendukung penulisan makalah ini yaitu Rektor Universitas Islam Balitar Blitar; Kemenristekdikti yang telah mendanai Penelitian dengan Dana Riset dan Pengabdian Masyarakat (DRPM) melalui skema Penelitian Dosen Pemula; dan semua pihak yang telah mendukung terlaksananya penelitian.

\section{DAFTAR PUSTAKA}

[1] Brahmana, S. S., Tantowi, F. Achmad. 2007. Dampak buangan lumpur panas porongsidoarjo terhadap kualitas air kali porong. JSDV 3(4):9-18.

[2] Hermanto, 2006. Lumpur Sidoarjo. Dialog Panjang Yang Tak Berkesudahan. http://www.antara.co.id/see Diakses 15 Agustus 2018.

[3] Rahayu, R.D. 2008. Pengaruh Pemanfaatan Bahan Organik Paitan (Thitonia diversifolia) kotoran Ayam, kotoran Sapi dan Lumpur Lapindo terhadap pH Tanah dan Kation Basa Tanah (DD) serta Pertumbuhan Tanaman Jagung (Zea mays) Pada Inceptisol Porong Sidoarjo. Agroteknologi. Fakultas Pertanian Universitas Brawijaya. Malang

[4] Andayani dan La Sarido, 2013. Uji Empat Jenis Pupuk Kandang Terhadap Pertumbuhan Dan Hasil Tanaman Cabai Keriting (Capsicum annum L.).Jurnal Agrifor7(1). Hal 22-29

[5] Smith SE., Read D. 2008. Mychorrhizal Symbiosis. Third Edition. Academic Press. Elsevier. New York.

[6] Goenadi, D.H., Siswanto, \& Sugiarto, Y. (2000). Bioactivation of poorly soluble phosphate rocks with a phosphorus solubilizing fungus. Soil Sci. Am. J., 64, 927-932.

[7] Simarmata, T. 1994. Teknologi Pupuk Organik. Dalam Akyas, A.M. T. Pudjianto, T. Simarmata, D. Widayat dan C. Tjahyadi (Eds). Penulisan Budidaya Buah-buahan (Mangga). Dirjen Tanaman Pangan, Departemen Pertanian: 143-152.

[8] Premsekhar M, Rajashree V. (2009). Influence of Organic Manures on Growth, Yield and Quality of Okra. American-Eurasian Journal of Sustainable Agriculture.

[9] Campbell, Neil, Reece, Jane B. dan Mitchell, Lawrence G. 2003 . Biology, Jilid 2, Terjemahan Wasmen Manalu. Jakarta: Erlangga.

[10] Wijaya K.A. 2008. Nutrisi Tanaman Sebagai Penentu Kualitas Hasil dan Resistensi Alami Tanaman . Jakarta: Prestasi Pustaka.

[11] Rafael. C, David. J, Walker, M. Pilar Bernal. 2005. Uptake of Heavy Metals and As by Brassica juncea Grown in a Contaminated Soil in Aznalcollar (Spain). Environmental Pollution. 138 (2005). 46-58.

[12] Musfal. 2010. Potensi Cendawan Mikoriza Arbuskula Untuk meningkatkan Hasil Tanaman jagung. J. Litbang Pertanian. 29(4):154-1581.

[13] Niswati, A. Nugroho, ,SG Utomo M. dan Suryadi. 1996. Pemanfaatan Mikoriza Vasikular Arbuskular untuk mengatasi Pertumbuhan Jagung Akibat Cekaman Kekeringan. Jurnal Ilmu Tanah Fakultas Pertanian: Universitas Lampung. No 3 Lampung. 
Army Dita Serdani \& Jeka Widiatmanta 2019. Respon Kandungan Logam Berat dan Pertumbuhan Tanaman Sawi (Brassica juncea) Terhadap Kombinasi Media Tanam Lumpur Lapindo dan Mikoriza Journal Viabel Pertanian. (2019), 13(2)16-25

[14] Kung'u, J. B. 2008. Effect Of Vesicular Arbuscular Mycorrhiza (VAM) Fungi Inoculation on Copping ability and Drought Resistance of Senna spectabilis. J. Botani. 40(5):2217- 2224.

[15] Syekhfani. 2009. Hubungan Hara Air Tanah dan Tanaman.Dasar-Dasar Aplikasi dan Pengelolaan Tanah Subur Berkelanjutan. PMN. Malang 